\title{
Cultural, Social, and National Setting and the Most Common Factor that Hinders Women's Empowerment
}

\author{
Anna C. Bocar \\ MBA, LL.B., DBA \\ Gulf College, Sultanate of Oman \\ Amal Salem Mohammed Al Wahaibi \\ Student-Researcher \\ Gulf College, Sultanate of Oman
}

\begin{abstract}
This study focused on the extent of women's empowerment in terms of cultural, societal, and national setting. It also determine the most common factor that hinders their empowerment. The result verified that the participants belong to the lower class. Furthermore, it was observed that their empowerment with respect to cultural and national setting is at very great extent. This signifies that they are empowered in this part most of the time. In terms of social setting they show that their empowerment is at great extent. It is revealed that illiteracy is the most common factor that hinders participants' empowerment. The study sealed that their socioeconomic status does not have an immense contribution to limit their empowerment on the cultural, social and national environment.
\end{abstract}

Keywords: cultural, social, national setting, women's empowerment, hindrances

\section{INTRODUCTION}

In a particular department there are groups of women who are designated to monitor the health of the people. This group of women are also assigned to some other functions of this department in the city. They are asked to help their colleagues in the department during times that there are activities that the government wants to extend to the people. It is expected that the people they are dealing with have different attitudes. In order to cope up with the varied attitudes of the people this group of women must possess wide knowledge, understanding and empowerment on the different aspects in life. Thus, the researchers desire to assess the extent of women's empowerment in this community in terms of cultural, societal, and national setting.

\section{Review of Related Literature}

Different researchers define SES in various manner. Commonly, SES has three levels: low, moderate, and high (Woolfolk, 2007 as cited in Brogan, 2009). According to Brogan (2009), "SES is the measure of the influence that the social environment has on individuals, families, communities, and schools. The educational level of the mother is closely associated to these factors". Mostly, low SES is associated with families at the poverty level. The preceding definition is more or less the same with what was said by Demarest, Reisner, Anderson, Humphrey, Farquhar, and Stein (1993) that, a family's socioeconomic status is based on family income, parental education level, parental occupation, and social status in the community (such as contacts within the community, group associations, and the community's perception of the family) ( as cited in "Socioeconomic Status", n.d.). Based on Fact Sheet (2013), low SES among women and the circumstances that are associated to it such as poverty, lower education, and poor health for children and families, ultimately affect overall well-being and 
quality of life of a person and to our society as a whole. Education is considered one of the most important means to empower women with the knowledge, skills and self-confidence which are necessary to participate fully in development processes.

The word empowerment is very popular; however it is one of the least understood in terms of how it is to be measured or observed (Suryanarayana et al., 2010). Page and Czuba, (1999) defines "empowerment as a multi-dimensional social process that helps people gain control over their own lives". This definition gives rise to the idea that a person who is empowered will be able to act on issues which they believe important for themselves, their own lives, communities societies and for their country at large. More or less a similar definition was given by Namtip Aksornkool ( as cited in Suryanarayana et al., 2010) by saying that "empowerment is a process in which women gain control over their own lives by knowing and claiming their rights at all levels of society at the international, local, and household levels". According to United Nations Population Fund, (2008) "women's empowerment is vital to sustainable development and the realization of human rights for all". It is more difficult for the family to succeed when the family size is large and the increase in the number of family members could be contributed by the low status of woman in the family. However, when the woman is empowered the whole family will be benefited. This advantage will descend to the future generation. The paper of Suryanarayana et al., (2010) expressed an agreement to the online article titled Guidelines on Women's Empowerment (n.d.) when they pointed out that "an empowered individual would be one who experiences a sense of self-confidence and selfworth; a person who critically analyzes his/her social and political environment; a person who is able to exercise control over decisions that affect his/her life". Furthermore they suggested other components for women empowerment and these are ... "cultural and communal aspects; information and lessons on politics; and provision of planning and thinking skills". They further elaborated that women should know that they can act upon to improve their situation.

\section{Conceptual Framework}

The researcher made questionnaire inspired by the paper of Suryanarayana, Raju, Himabindu, and Alekhya, (2010) was employed. The schematic diagram below illustrates the significant components that encourage the development of this study.

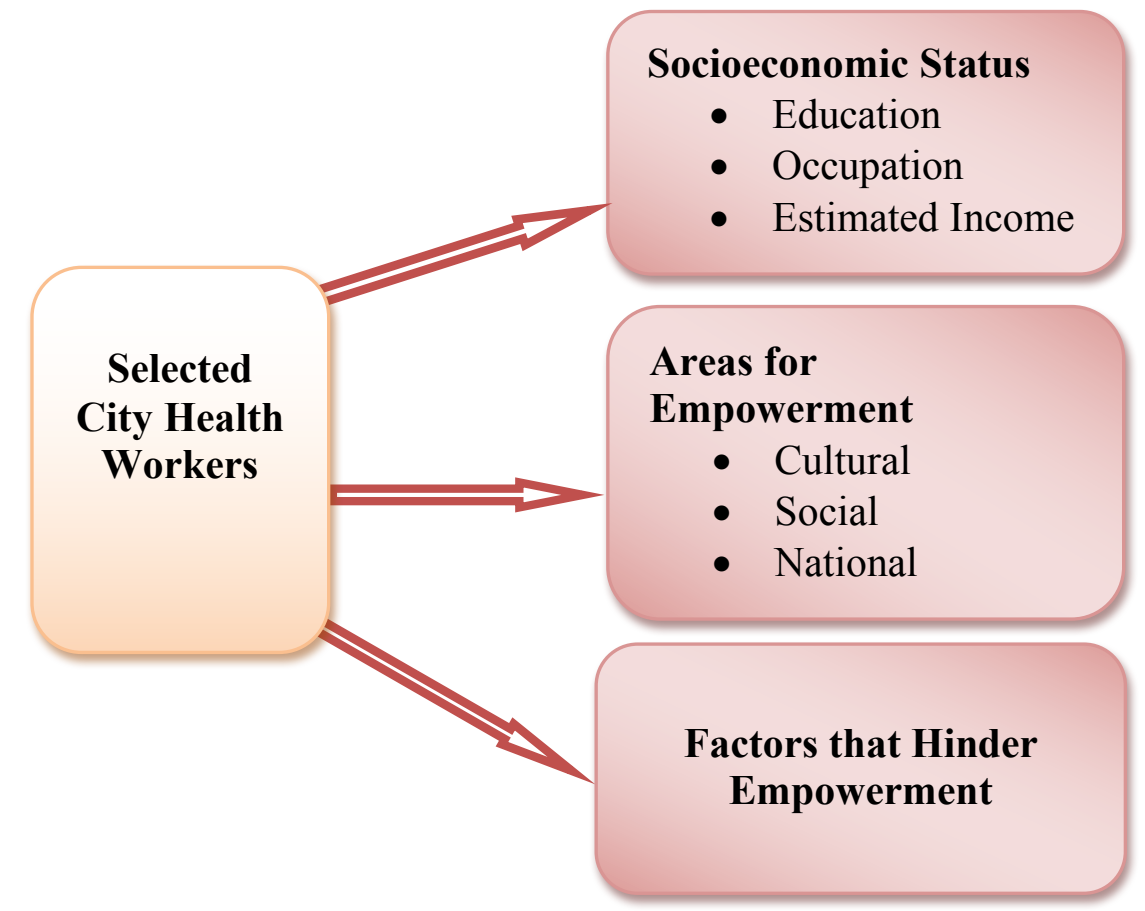

Figure 1. Schematic diagram: The Research Components 


\section{The Problems}

There are three main questions that the researchers specifically sought to answer, namely: (1) What is the socioeconomic status of the selected health workers? (2) What is the extent of women's empowerment in terms of cultural; social, and national setting? (3) What is the most common factor that hinders participants' empowerment?

\section{Significance of the Study}

This study is significant to the different groups of people more specifically those who are in charge with the health of the citizens. They can utilize the result of this study to enhance the empowerment of the women in the said city. The findings of this study would add to the sets of valuable literature that are useful for future research endeavor which are related to this issue.

\section{METHOD}

The descriptive research method is utilized in this investigative work. A researcher made survey checklist form extracted from the paper of Suryanarayana, Raju, Himabindu, and Alekhya, (2010) with slight modifications in some terminologies is the main instrument used in this study to gather the data. The extent of participants' empowerment in terms of cultural, social and national context is measured by different indicators which are mentioned in Table 2, 3 , and 4 below. On the other hand, the factors that hinders women empowerment are also mentioned in Table 5. All 26 employees who are working in the health sector in one of the cities in the subject country are the participants of this study. They are considered as the respondents of this study on the reason that they are more often involved in the services offered by the government; thus, the extent of their empowerment is essential to their job.

\section{Statistical Tools and Treatment of Data}

The frequency and percentile distribution were used for the interpretation of the SES of the participants. Further, the researchers constructed a four scale qualitative measurement. These are: none at all (never empowered); less great extent ( sometimes); great extent (often times); and very great extent (empowered most of the time) to describe the gathered data as regards to the extent of women's empowerment on the areas of cultural, social and national setting. Numeric value is assigned to each qualitative scale that ranges from 1 as the lowest value to 4 as the highest value. Hypothetical mean range was also specified to give accurate value on participant's answers as follows (from lowest to highest range): 1.00-1.75; 1.76 $2.50 ; 2.51-3.25 ; 3.26-4.00$ ). Moreover, though the four qualitative descriptions, namely: seldom (infrequently), occasionally (majority of the time), frequently (most of the time), always (at all times) are utilized, the frequency and percentile distribution are also employed to determine the most common factor that hinders the participants' empowerment.

\section{Data Gathering and Scoring Procedure}

The accomplished questionnaires were collected and the responses to each instrument were tallied. The data are then processed and tabulated. The frequency and percentage of some items were noted. The scales used by Guidance Center of La Salle Academy in SY $1999-2000$ ( as cited in Ejercito, 2010) are utilized to determine the participants" social class grouping with slight modification as regards to monthly family income.

The Figure 2 below illustrated the weighing and scoring scales of the SES indicators such as education, occupation, and the combined monthly family income. 
Bocar, A. C., \& Al Wahaibi, A. S. M. (2018). Cultural, Social, and National Setting and the Most Common Factor that Hinders Women's Empowerment. Advances in Social Sciences Research Journal, 5(3) 43-50.

Figure 2. Weighing and Scoring Scales of the SES indicators

\begin{tabular}{|c|c|c|}
\hline Education & \multicolumn{2}{|c|}{ Points } \\
\hline Not elementary graduate & \multicolumn{2}{|c|}{2} \\
\hline Elementary level & \multicolumn{2}{|c|}{3} \\
\hline Elementary graduate & \multicolumn{2}{|c|}{4} \\
\hline High school level & \multicolumn{2}{|c|}{5} \\
\hline High school graduate & \multicolumn{2}{|c|}{6} \\
\hline College level & \multicolumn{2}{|c|}{7} \\
\hline College graduate & \multicolumn{2}{|c|}{8} \\
\hline Masters Degree & \multicolumn{2}{|c|}{9} \\
\hline Doctorate Degree & \multicolumn{2}{|c|}{10} \\
\hline \multicolumn{3}{|l|}{ Occupation } \\
\hline & Category & Points \\
\hline $\begin{array}{l}\text { Top Government Official, College Professor, } \\
\text { Lawyer, Engineer, Business Executives, Manager of Own } \\
\text { Business, Scientist }\end{array}$ & A & 10 \\
\hline $\begin{array}{l}\text { Government Employee, Teacher, Nurse, Military, Police, } \\
\text { Supervisor, Top Salesman, Foreman, Transportation Operator, } \\
\text { Technician }\end{array}$ & B & 8 \\
\hline $\begin{array}{l}\text { Private Employee, Clerical Worker, Salesman, Driver, Mechanic, } \\
\text { Seaman, OFW, Service Recreational Worker, Skilled Laborers }\end{array}$ & $\mathrm{C}$ & 6 \\
\hline $\begin{array}{l}\text { Fisherman, Farmer, Carpenter, Vendor, Store Keeper, Self- } \\
\text { employed, Hunter, Logger, Unskilled Manual Laborer }\end{array}$ & $\mathrm{D}$ & 4 \\
\hline Retired Employee, Pensionado & E & 2 \\
\hline Non-working or housekeeper & $\mathrm{F}$ & 0 \\
\hline Monthly Family Income (in terms OMR) & \multicolumn{2}{|c|}{ Points } \\
\hline $9,001-10,000.00$ and above & \multicolumn{2}{|c|}{80} \\
\hline $8,001-9,000$ & \multirow{2}{*}{\multicolumn{2}{|c|}{$\begin{array}{l}72 \\
64\end{array}$}} \\
\hline $7,001-8,000$ & & \\
\hline $6,001-7,000$ & \multicolumn{2}{|c|}{$\begin{array}{l}64 \\
56\end{array}$} \\
\hline $5,001-6,000$ & \multicolumn{2}{|c|}{48} \\
\hline $4,001-5,000$ & \multicolumn{2}{|c|}{40} \\
\hline $3,001-4,000$ & \multicolumn{2}{|c|}{32} \\
\hline $2,001-3,000$ & \multicolumn{2}{|c|}{24} \\
\hline $1,001-2,000$ & \multicolumn{2}{|c|}{16} \\
\hline 1,000 - below & \multicolumn{2}{|c|}{8} \\
\hline
\end{tabular}

Based on the answers of the participants and with the utilization of the scales used by Guidance Center of La Salle Academy in SY 1999 - 2000 ( as cited in Ejercito, 2010), the points that correspond to the item as indicated above be summed up, and from the total scores that are obtained as regards to participants' education, occupation, and combined monthly family income the social class groupings are determined as follows:

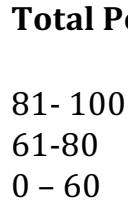

Total Points

$61-80$

$0-60$

\section{Social Class}

Upper Class ( High SES )

Middle Class ( Middle SES )

Lower Class ( Low SES )

The researchers made some modifications as to the amount of income. The Omani Rial (OMR) becomes the value of the currency used to suit the participants' combined income. 


\section{Socioeconomic Status}

\section{RESULTS AND DISCUSSION}

Brogan (2009) stated, "Socioeconomic Status (SES) classifications are established in an effort to find the means of identifying and changing inequalities". Furthermore, he stressed "SES is the measure of the influence that the social environment has on individuals, families, and communities. In this study, it shows that the participants are having the same level of their socioeconomic status. Apparently, one hundred percent $(100 \%)$ of the participants belong to the lower class.

Table 1

Participants' Socioeconomic Status

\begin{tabular}{|l|l|c|c|}
\hline Social Class Grouping & \multicolumn{1}{|c|}{ Total Points } & F & $\%$ \\
\hline Upper Class & $81-100$ & - & - \\
\hline Middle Class & $61-80$ & - & - \\
\hline Lower Class & $0-60$ & 26 & 100 \\
\hline
\end{tabular}

This results could be an open illustration of the statement in the Fact Sheet (2013), which says that "disparities in the distribution of wealth, income, and access to resources, affects everyone". Furthermore, it continued revealing that negative psychological and physical health outcomes on women are linked with low SES. Moreover, it mentioned that low SES among women ultimately affects the overall well-being and quality of life of a person and to the society as a whole.

\section{Cultural Empowerment}

The role of men and women in the society are socially determined and these roles differ by locality and it changes from time to time. Women's empowerment is important to maintain progress and the comprehension of human rights ("United Nations Population Fund", 2008). The table below highlights the results as regards to the extent of participants' cultural empowerment.

Table 2

Extent of Participants' Cultural Empowerment

\begin{tabular}{|l|c|c|}
\hline Cultural Empowerment Indicators & $\begin{array}{c}\text { Item Average } \\
(\boldsymbol{\mu})\end{array}$ & QD \\
\hline 1. Extent of participation in crucial decision-making processes & 3.19 & $\mathrm{GE}$ \\
\hline 2. Scope of sharing of domestic work by men & 3.12 & $\mathrm{GE}$ \\
\hline 3. Feeling and expression of pride and value of work & 3.35 & VGE \\
\hline 4. Self-confidence and self-esteem & 3.50 & VGE \\
\hline 5. Ability to prevent violence & 3.27 & VGE \\
\hline Factor Average & $\mathbf{3 . 2 9}$ & VGE \\
\hline
\end{tabular}

The results showed that among the five indicators of cultural empowerment the participants' self-confidence and self-esteem is at very great extent $(\mu=3.50)$. It clearly shows that this particular result elevated the entire cultural empowerment of the participants. They are empowered most of the time when it comes to the cultural aspects in their environment.

\section{Social Empowerment}

As presented in the table below, it can be grasped from its factor average $(\mu=2.95)$ that participants' social empowerment is at great extent. It is noticeable in the indicators for social empowerment mentioned below that none of them garnered with a low or high item average in its weighted mean. This signifies that in its entirety the participants are often times empowered when it comes to matters in the society. 
Table 3

Extent of Participants' Social Empowerment

\begin{tabular}{|l|c|c|}
\hline \multicolumn{1}{|c|}{ Social Empowerment Indicators } & $\begin{array}{c}\text { Item Average } \\
(\boldsymbol{\mu})\end{array}$ & QD \\
\hline 1. Existence of women's organizations & 2.88 & GE \\
\hline 2. Allocation of funds for women and women's projects & 3.04 & GE \\
\hline $\begin{array}{l}\text { 3. Increase number of women leaders at the community, city, } \\
\text { municipality, state and national levels }\end{array}$ & 2.92 & GE \\
\hline $\begin{array}{l}\text { 4. Involvement of women in the design, development and application of } \\
\text { technology }\end{array}$ & 3.15 & GE \\
\hline 5. Involvement in community programs & 3.19 & GE \\
\hline 6. Contribution in productive enterprises & 3.00 & GE \\
\hline 7. Participation in politics and arts & 2.81 & GE \\
\hline 8. Involvement of women in non-traditional tasks & 2.73 & GE \\
\hline 9. Increase training programs for women & 2.62 & GE \\
\hline 10. Exercising women's legal rights when necessary & 3.12 & GE \\
\hline Factor Average & $\mathbf{2 . 9 5}$ & GE \\
\hline
\end{tabular}

The study of Adamson, (2010) identified some barriers to achieve empowerment such as organizational cultures and regulatory frameworks. Women of today must have enough knowledge of some characteristics and traits in the organization in order that these would not hinder them to succeed. The present time requires great focus since less attentiveness and preparedness to relevant issues may manifest lack of empowerment. Adamson, (2010) also added that to improve participation and empowerment procedures must be established. His statement does some agreement on the indicators mentioned on the Table 3 . While, in the findings of Varghese (2011) she stated "women in the Oman are better in household decision making and economic decision making than social empowerment". The time being, this result does a difference on the reason that the participants are coming from another region of the Sultanate of Oman.

\section{National Empowerment}

The results presented in Table 4 below highlights the national empowerment of the participants. It is clear in the result that the two (Nos. 4 and 5) out of five indicators are considered by the women-participants at great extent. This means that at often times they are empowered in terms of national aspects. On the other hand, three of the five indicators (Nos. 1, 2 , and 3) are well-thought by the participants with the results of at very great extent. This signifies that alongside they are empowered most of the time in some point.

Table 4

Participants' National Empowerment

\begin{tabular}{|l|c|c|}
\hline National Empowerment Indicators & $\begin{array}{c}\text { Item Average } \\
(\boldsymbol{\mu})\end{array}$ & QD \\
\hline 1. awareness of my social rights & 3.65 & VGE \\
\hline 2. consciousness of women's political rights & 3.42 & VGE \\
\hline 3. integration of women in the general national development plan & 3.31 & VGE \\
\hline 4. existence of women's networks and publications & 3.23 & GE \\
\hline 5. deliberation by the media take on women's issues & 3.00 & GE \\
\hline Factor Average & $\mathbf{3 . 3 2}$ & VGE \\
\hline
\end{tabular}

Furthermore, it is interesting to note that based on the overall results the women-participants' national empowerment is at very great extent. It indicates that they are empowered most of the time in relation to national matters. This result is somewhat similar to the findings of a research which was conducted in another region of the Sultanate of Oman. It revealed that 
majority of their participants (women) are aware of their rights and duties related to issues in legal and political end (Varghese, 2011).

\section{Factors that Hinder Participants' Empowerment}

In the paper of Eldred, (2013) she discussed empowerment as a means of being equipped to take a better control of ones' life, including education. In the vision of a certain organization it was said that "the most vulnerable people in the world will have the power to lift themselves out of poverty and to create vital, healthy lives for their families and communities". However, it is also held that even though they have the power to boost themselves to get away from poverty they need more empowerment since there are many other aspects in the world which may hinder them to attain their goals. Women in particular need empowerment. In fact it was specifically mentioned by ("Project Concern International", 2016) that empowered women turn into the solution to poverty and poor health.

The Table 5 below presents the most common factors that hinder women empowerment. Loaded with the nine indicators only one of them was considered as seldom or infrequently a hindrance towards women's empowerment. Moreover, four of the factors appear as an impediment to women's empowerment occasionally or majority of the time.

Table 5

Most Common Factors that Hinder Women Empowerment

\begin{tabular}{|l|c|c|}
\hline Factors that Hinder Women Empowerment & $\begin{array}{c}\text { Item Average } \\
(\boldsymbol{\mu})\end{array}$ & QD \\
\hline 1. heavy work load & 2.08 & Occ \\
\hline 2. isolation/remoteness of women from each other & 2.27 & Occ \\
\hline 3. illiteracy & 3.19 & F \\
\hline 4. participation is limited due to traditional views & 2.62 & $\mathrm{~F}$ \\
\hline 5. no funds & 2.85 & $\mathrm{~F}$ \\
\hline 6. internal conflict/militarization/wars & 1.96 & $\mathrm{~S}$ \\
\hline 7. disagreements/conflicts among women's groups & 2.62 & $\mathrm{~F}$ \\
\hline 8. discriminatory policy in the environment & 2.15 & Occ \\
\hline 9. negative and sensational coverage of media & 2.19 & Occ \\
\hline
\end{tabular}

Meanwhile, the other four of the factors are pointed out by the participants as the main reasons that frequently (most of the time) impede women's empowerment. These four factors occupied the mean range of 2.51 - 3.25.; however, illiteracy ( $\mu=3.19)$ shows the higher item average among them. The result indicates that frequently illiteracy hindered most to women empowerment. The Oxford dictionary defines illiteracy as lack of knowledge in a particular subject and subject could mean an issue, concern, gist or matter to which in one way or another affects one's life or existence. In the study of Eldred, (2013) she stressed that literacy is important since it is a value added to communication and learning and it could be a guide towards empowerment.

\section{FINDINGS}

Based on the gathered data the researchers found the following:

1. the socioeconomic status of the $100 \%$ participants of this study is at the lower class;

2. participants revealed that they are empowered at very great extent or most of the time when it comes to the cultural aspects in their environment;

3. the participants disclosed that they are empowered at great extent or often times when it comes to social matters;

4. there is a split results in terms of women's empowerment in national aspects; however, the difference shown is with little significance considering that the overall 
results are at very great extent or participants are empowered most of the time in relation to national matters;

5. the most common factor that hinders participants' empowerment is illiteracy

\section{CONCLUSION}

In the context of the findings of this study the researchers conclude that the socioeconomic status of the participants does not have an immense contribution to limit their empowerment on the cultural, social and national setting since the participants revealed that their empowerment in cultural and national setting are at very great extent while in the social setting is at great extent. The discoveries shown in this study are found to be not completely in agreement to some parts of other researchers' outcome as regards to these topics. Furthermore, as manifested by the participants, illiteracy is the foremost reason that hinders empowerment. Literally, any particular educational level in which may involve money is not only what literacy all about. It refers also to competence or knowledge, the know-how attitude of a person, to a specific area.

\section{References}

Adamson, D. (2010) "Community empowerment: Identifying the barriers to "purposeful" citizen participation", International Journal of Sociology and Social Policy, Vol. 30 Iss: 3/4, pp.114 - 126. Publisher: Emerald Group Publishing Limited. Date retrieved: June 7, 2016 Available from http://www.emeraldinsight.com/doi/abs/10.1108/01443331011033319

Brogan, R. (2009). Socioeconomic status. The Gale Group. Date retrieved May 10, 2013. Available from http://www.education.com/reference/article/socioeconomic-status/

Ejercito, F. (2010). Socioeconomic Profile of LSU Students. Lasallian Research Forum. Volume 14. No.7

Eldred, J. (2013). Literacy and Women's Empowerment. Date retrieved September 14, 2016. Available from http://unesdoc.unesco.org/images/0022/002234/223466e.pdf. UNESCO Institute for Lifelong Learning. Feldbrunnenstraße 58. 20148 Hamburg Germany. ISBN 978-92-820-1183-6

Fact sheet: Women \& socioeconomic status. (2013). American Psychological Association. 750 First Street NE, Washington, DC 20002-4242. Date retrieved May 15, 2013. Available from http://www.apa.org/pi/ses/resources/publications/factsheet-women.aspx

Guidelines on Women's Empowerment. (n.d.).Women's empowerment: A definition. UNITED NATIONS POPULATION INFORMATION NETWORK (POPIN) UN Population Division, Department of Economic and Social Affairs, with support from the UN Population Fund (UNFPA). Date retrieved January 20, 2013 Available from http://www.un.org/popin/unfpa/taskforce/guide/iatfwemp.gdl.html

Page, N. \& Czuba, C. (1999). Empowerment: What Is It? Extension Journal, Inc. ISSN 1077- 5315 Volume 37 // Number 5 //. Date retrieved January 20. 2013. Available from http://www.joe.org/joe/1999october/comm1.php

Project Concern International (PCI). (2016). Great Courage and PCI are Empowering Women. San Diego. Date retrieved June 7, 2016. Available from

https://www.pciglobal.org/empoweringwomen/?gclid=CLOpmerklc0CFcrjGwodXAsB3w

Socioeconomic Status. (nod) Date retrieved May 10, 2013. Available from

http://www.ncrel.org/sdrs/areas/issues/students/earlycld/ea7lk5.htm. North Central Regional Educational Laboratory.

Suryanarayana, N.V.S., Raju, T.J.M.S., Himabindu, G., \& Alekhya, CH. (2010). Women empowerment - Types and ways. Date retrieved January 20, 2013. Available from http://www.hillhouseoperacompany.org/womenenpowerment-varieties-and-ways.html

United Nations Population Fund. (2008). Gender equality. Empowering women. Date retrieved January 20, 2013 from http://www.unfpa.org/gender/empowerment.htm

Varghese, T. (2011). Women Empowerment in Oman: A study based on Women Empowerment Index. Date retrieved September 13, 2016. Available from https://www.researchgate.net/publication/50829269_Women_Empowerment_in_Oman_A_study_based_on_Wom en Empowerment Index. 